JURNAL KEBIDANAN

Tersedia online di https://akbid-dharmahusada-kediri.e-journal.id/JKDH/index

\title{
HUBUNGAN PENGETAHUAN DENGAN TINGKAT KECEMASAN WANITA PREMENOPAUSE DALAM MENGHADAPI MASA MENOPAUSE
}

\author{
Betristasia Puspitasari \\ Akbid Dharma Husada Kediri \\ Email :betristasya@gmail.com \\ I N F O A R T I K E L \\ Sejarah artikel: \\ Menerima 10 Agustus 2020 \\ Revisi 22 September 2020 \\ Diterima 1 Oktober 2020 \\ Online 10 Oktober 2020
}

\section{Kata kunci:}

Pengetahuan, Tingkat

Kecemasan, Wanita,

Premenopause, Masa

Menopause

\section{Keywords:}

Knowledge, anxiety level, women, Premenopause, Menopause period

\author{
Style Mendeley dalam \\ menyitasi artikel ini: \\ Puspitasari,B.(2020). \\ Hubungan Pengetahuan Dengan \\ Tingkat Kecemasan Wanita \\ Premenopause Dalam \\ Menghadapi Masa Menopause \\ JKDH; Jurnal Kebidanan; \\ 9(2), 115 - 119
}

\begin{abstract}
ABSTRAK
Menopause dikenal sebagai waktu penghentian menstruasi secara permanen yang terjadi menyusul hilangnya aktivitas ovarium. Perubahan-perubahan yang terjadi secara fisik, psikis maupun seksual akan menyebabkan wanita yang sedang menghadapi menopause cemas dan khawatir. Tujuan penelitian ini untuk mengetahui hubungan pengetahuan dengan tingkat kecemasan wanita premenopause dalam menghadapi masa menopause. Desain penelitian ini menggunakan desain korelasional dengan pendekatan Croos Sectional. Populasi dalam penelitian ini adalah wanita premenopause, pengambilan sampel menggunakan teknik total sampling didapatkan sampel sebanyak 36 responden. Variabel dalam penelitian ini variable independen adalah Pengetahuan Wanita Premenopause Tentang Menopause dan variabel dependen adalah Tingkat Kecemasan Wanita Premenopause dalam Menghadapi Masa Menopause. Instrument pada penelitian ini berupa kuesioner pengetahuan dan kuesioner skala HARS. Data yang diperoleh diolah dengan editing, coding, scoring, tabulating dan dideskripsikan. Dari hasil penelitian didapatkan dari 36 responden, sebagian besar responden yang berpengetahuan cukup dengan kecemasan ringan sebanyak 11 responden (30,5\%). Maka dapat disimpulkan ada hubungan pengetahuan dengan tingkat kecemasan wanita premenopause dalam menghadapi masa menopause. Berdasarkan hasil penelitian, hendaknya informasi tentang menopause lebih ditingkatkan dengan penyuluhan sehingga ibu premenopause dapat menghadapi masa menopause tanpa kecemasan yang berlebih. Pengetahuan yang baik tentang menopause akan menjadi dasar ibu untuk menghadapi masa menopause dengan tenang.
\end{abstract}

\section{ABSTRACT}

\footnotetext{
Menopause is known as a permanent menstrual termination time that occurs following the loss of ovarian activity. Physical, psychic and sexual changes will cause women facing menopause to be anxious and worried. The purpose of this research is to know the knowledge relationship with the anxiety level of premenopausal woman in the face of menopause period. The design of this research uses correlational design with Croos Sectional. The population in this study was Premenopause women, sampling using a total sampling technique obtained as many as 36 respondents. Variables in this study of independent variables are Premenopause women's knowledge about Menopause and dependent variables are the anxiety levels of Premenopause women in the face of Menopause period. The Instrument in the study is a knowledge questionnaire and a HARS scale questionnaire. The Data obtained is processed by editing, coding, scoring, tabulating and described. From the results of the study obtained from 36 respondents, the majority of respondents were knowledgeable enough with mild anxiety as much as 11 respondents $(30.5 \%)$. It can be concluded that there is a relationship of knowledge with the anxiety level of premenopausal woman in the face of menopause period. Based on the results of the research, should information about menopause more enhanced by counseling so that premenopausal mother can face menopause without excessive anxiety. A good knowledge of menopause will be the basis for the mother to face menopause calmly.
} 


\section{JURNAL KEBIDANAN}

\section{PENDAHULUAN}

Tuhan menciptakan wanita sebagai makhluk yang terlahir dengan keindahan dan kelembutan. Setiap wanita akan menjaga keindahan yang telah di karuniakan Tuhan dan akan merasa cemas jika tidak bisa tampil indah lagi.

Dalam perjalanan hidupnya, wanita mengalami banyak proses pertumbuhan dan perkembangan, sampai suatu saat pertumbuhan dan perkembangan akan berhenti pada suatu tahapan sehingga terlalu banyak perubahan yang terjadi pada fungsi tubuh wanita. Perubahan ini akan terjadi seiring peningkatan usia sampai akhirnya wanita akan mencapai titik yang dinamakan menopause dan di titik ini kecemasan akan muncul karena merasa dirinya sudah tidak indah lagi.[1]

Menopause berasal dari bahasa Yunani, yang berarti "bulan", yang secara linguistic lebih tepat disebut "menocease" yang mengandung arti berhentinya masa menstruasi. Menopause dikenal sebagai waktu penghentian menstruasi secara permanen yang terjadi menyusul hilangnya aktivitas ovarium.[1]

Sebelum terjadi fase menopause biasanya di dahului fase premenopause, dimana pada fase pre menopause ini terjadi peralihan dari masa subur menuju masa tidak adanya pembuahan. Sebagian besar wanita mulai mengalami gejala pre menopause pada usia 40 an dan puncaknya tercapai pada usia 50 tahun yaitu terjadinya masa menopause. Gejala premenopause terjadi akibat menurunnya kadar estrogen tersebut menimbulkan gejala yang sangat mengganggu aktivitas kehidupan para wanita, bahkan mengancam kebahagiaan rumah tangga, masalah yang muncul yaitu hilangnya masa kesuburan dan meningkatnya perubahan yang menyebabkan kecemasan dan kekhawatiran pada wanita. Masalah yang timbul akibat premenopause ini disebut dengan sindrom pre menopause. Masalah yang terjadi berupa masalah fisik maupun psikologis. Sebagian wanita belum mengerti bahkan tidak mengetahui kalau mereka berada pada masa ini.[2]

Perubahan fisiologis yang dialami wanita menopause berupa perubahan pada organ reproduksi (Tuba Fallopi, Serviks, Vagina, Dasar Panggul, perineum dan anus, vesica urinaria, kelenjar payudara. Adapun perubahan pada organ di luar reproduksi (Adipositas penimbunan lemak, hipertensi, kolesterol tinggi, perkapuran dinding pembuluh darah, pertumbuhan rambut-rambut halus, keropos tulang ).[3]

Adanya perubahan hormone dan keluhan-keluhan pada wanita usia lanjut tersebut akan mempengaruhi ketidaknyamanan wanita. [4]

Perubahan-perubahan yang terjadi secara fisik, psikis maupun seksual akan menyebabkan wanita yang sedang menghadapi menopause cemas dan khawatir. Kecemasan yang mereka alami sering dihubungkan dengan kekhawatiran dalam menghadapi situasi yang sebelumnya belum pernah terjadi.[5]

Sebagian wanita dihantui oleh istilah menopause, berpikir ketika suatu saat nanti menopause menghampirinya. Seorang wanita ditengah-tengah tahun kehidupannya dikelilingi oleh mitos-mitos yang berkembang dikalangan wanita tentang menopause. Mitos-mitos ini dapat menimbulkan banyak ketakutan dan kecemasan dalam kehidupan wanita. Terutama wanita paruh baya ketika mereka mendekati masa menopause padahal mitos itu belum tentu benar.[1]

Data WHO (2015) menyebutkan jumlah wanita pre menopause di Asia pada tahun 2010 mencapai 373 juta jiwa, berdasarkan data Kementrian Kesehatan RI, secara nasional pada tahun 2015 jumlah wanita yang memasuki pre menopause yaitu berusia antara 40 tahun sebanyak 9,09 juta orang. Pada tahun 2015 di Propinsi Jawa Timur jumlah wanita yang memasuki masa pre menopause sebesar 1,51 juta orang. Data di Kabupaten Kediri jumlah keseluruhan pre menopause 60.067 juta orang.[6]

Perubahan psikis yang terjadi pada masa menopause dapat menimbulkan sikap yang berbedabeda, diantaranya yaitu adanya suatu krisis yang dimanifestikan dalam syimptom psikologi sepeerti depresi, mudah marah, mudah curiga, diliputi banyak kecemasan, insomnia atau tidak bisa tidur, karena sangat bingung dan gelisah.[7]

Banyak wanita yang mengalami menopause menjadi seorang yang mudah mengalami rasa cemas. Kecemasan ini timbul sebagai akibat seringnya kekhawatiran yang menghantui dalam menghadapi situasi yang sebelumnya tidak pernah mereka khawatirkan. Salah satu faktor yang menyebabkan wanita menopause merasa cemas adalah

Jurnal Kebidanan Vol 9 No 2 Oktober 2020|116 


\section{JURNAL KEBIDANAN}

ketidaktahuan wanita tersebut akan tanda/ciri-ciri dari menopause padahal dia sudah memasuki fase itu.[8]

Umumnya mereka tidak mendapat informasi yang. benar sehingga yang dibayangkan adalah efek negatif yang akan dialami setelah memasuki masa pre menopause dan menopause. Mereka cemas menjelang berakhirnya era reproduksi yang berarti berhentinya nafsu seksual dan fisik. [2]

Kecemasan yang berlebihan dapat menimbulkan dampak buruk bagi tubuh. Rasa yang berlebihan itulah yang memacu organ tubuh tidak stabil. Tentunya hal ini membuat wanita menopause merasa terganggu dalam menjalankan kegiatan sehari-hari. [7]

Penanganan yang dilakukan untuk mencegah semua dampak akibat kecemasan pada wanita menopause, sebagian wanita menanganinya dengan melakukan meditasi, atau dengan mengelola tingkat kecemasan, tertawa, dan teknik relaksasi. [1]

Menambah pengetahuan para ibu yang berusia 4550 tahun dapat mengurangi kecemasan pada ibu dalam menghadapi masa menopause. Untuk itu tenaga kesehatan diharapkan dapat membantu mengatasi kecemasan ibu menghadapai menopause dengan memberikan penyuluhan. Penyuluhan tersebut bisa berupa penyuluhan mengenai tanda, gejala, faktor, perubahan-perubahan fisik maupun psikologi sehingga dalam menghadapi masa menopause sehingga tidak menimbulkan rasa cemas yang berlebihan.

Berdasarkan uraian permasalahan diatas maka peneliti tertarik untuk melakukan penelitian dengan judul Hubungan Pengetahuan dengan Tingkat Kecemasan Wanita Premenopause Dalam Menghadapi
Masa Menopause di RT 15-17 Ds. Joho Kec. Wates Kab. Kediri.

\section{METODE PENELITIAN}

Penelitian atau research merupakan kegiatan yang menghasilkan suatu karya tulis berdasarkan kenyataan ilmiah. [9] Desain penelitian ini menggunakan penelitian korelasional dengan pendekatan cross sectional. Penelitian korelasional mengkaji hubungan antara variabel. Dengan demikian, pada rancangan penelitian korelasional peneliti melibatklan minimal dua variabel. [10]

Pendekatan cross sectional adalah suatu penelitian untuk mempelajari korelasi antara faktor-faktor risiko dengan cara pendekatan/pengumpulan data sekaligus pada satu saat tertentu saja. Studi ini dapat diterapkan pada penelitian deskriptif maupun analitik. [11]

Penelitian ini merupakan penelitian korelasional dengan pendekatan Cross Sectional. Populasi pada penelitian ini adalah semua wanita premenopause di RT 15-17 Ds Joho Kec. Wates Kabupaten Kediri sebanyak 36 responden dengan menggunakan teknik total sampling.

Variabel dalam penelitian ini variable independen adalah Pengetahuan Wanita Premenopause Tentang Menopause dan variabel dependen adalah Tingkat Kecemasan Wanita Premenopause dalam Menghadapi Masa Menopause.

Pengumpulan data dilakukan dengan menggunakan kuesioner pengetahuan dan kuesioner skala HARS. Pengolahan data melalui editing, coding, scoring, tabulating dan dideskripsikan.

\section{DISKUSI}

Tabel 1. Hubungan Pengetahuan dengan Tingkat Kecemasan Wanita Premenopause dalam menghadapi menopause

\begin{tabular}{|c|c|c|c|c|c|c|c|c|c|c|c|c|c|}
\hline \multirow{3}{*}{ No } & \multirow{3}{*}{ Pengetahuan } & \multicolumn{10}{|c|}{ Tingkat Kecemasan } & \multirow{2}{*}{\multicolumn{2}{|c|}{ Jumlah }} \\
\hline & & \multicolumn{2}{|c|}{ Tidak Cemas } & \multicolumn{2}{|c|}{ Ringan } & \multicolumn{2}{|c|}{ Sedang } & \multicolumn{2}{|c|}{ Berat } & \multicolumn{2}{|c|}{ Sangat Berat } & & \\
\hline & & $\Sigma$ & $\%$ & $\Sigma$ & $\%$ & $\Sigma$ & $\%$ & $\Sigma$ & $\%$ & $\Sigma$ & $\%$ & $\Sigma$ & $\%$ \\
\hline 1 & Baik & 3 & 8,3 & 6 & 16,7 & 0 & 0 & 0 & 0 & 0 & 0 & 9 & 25 \\
\hline 2 & Cukup & 2 & 5,6 & 11 & 30,5 & 2 & 5,6 & 0 & 0 & 0 & 0 & 15 & 41,7 \\
\hline \multirow[t]{2}{*}{3} & Kurang & 0 & 0 & 6 & 16,7 & 3 & 8,3 & 3 & 8,3 & 0 & 0 & 12 & 33,3 \\
\hline & Total & 5 & 13,9 & 23 & 63,9 & 5 & 13,9 & 3 & 8,3 & 0 & 0 & 36 & 100 \\
\hline
\end{tabular}

Dari hasil penelitian dapat dideskripsikan bahwa sebagian besar responden yang berpengetahuan baik dengan kecemasan ringan sebanyak 6 responden $(16,7 \%)$, berpengetahuan baik tidak cemas sebanyak 3 responden $(8,3 \%)$, dan tidak ada responden yang berpengetahuan baik dengan kecemasan sedang, kecemasan berat dan kecemasan sangat berat $(0 \%)$. Sebagian besar responden yang berpengetahuan cukup 
dengan kecemasan ringan sebanyak 11 responden $(30,5 \%)$, berpengetahuan cukup tidak cemas sebanyak 2 responden $(5,6 \%)$, berpengetahuan cukup dengan kecemasan sedang sebanyak 2 responden $(5,6 \%)$, dan tidak ada responden yang berpengetahuan cukup dengan kecemasan berat dan kecemasan sangat berat $(0 \%)$. Sebagian besar responden yang berpengetahuan kurang dengan kecemasan ringan sebanyak 6 responden $(16,7 \%)$, berpengetahuan kurang dengan kecemasan sedang sebanyak 3 responden $(8,3 \%)$, berpengetahuan kurang dengan kecemasan berat sebanyak 3 responden $(8,3 \%)$, dan tidak ada responden yang berpengetahuan kurang dengan kecemasan sangat berat dan tidak cemas $(0 \%)$. Maka dari hasil penelitian dapat disimpulkan bahwa ada hubungan pengetahuan dengan tingkat kecemasan wanita premenopause dalam menghadapi masa menopause Ada hubungan pengetahuan dengan tingkat kecemasan wanita premenopause dalam menghadapi masa menopause.

Ada hubungan pengetahuan dengan tingkat kecemasan wanita premenopause dalam menghadapi masa menopause.

Pengetahuan yang rendah mengakibatkan seseorang mudah mengalami stres. Ketidaktahuan terhadap suatu hal dianggap sebagai tekanan yang dapat mengakibatkan krisis dan dapat menimbulkan kecemasan. Stres

dan kecemasan dapat terjadi pada individu dengan tingkat pengetahuan yang rendah, disebabkan karean kurangnya informasi yang diperoleh. [12]

Dalam teori dijelaskan pengetahuan memiliki peran penting dalam menentukan tingkat kecemasan seseorang. Pengetahuan dan pengalaman yang dimiliki seseorang juga dapat menentukan sikap orang tersebut dalam kehidupannya. Hasil yang didapatkan dari data penelitian tersebut bahwa wanita premenopause yang mempunyai pengetahuan cukup tentang menopause memiliki tingkat kecemasan ringan. Hal ini menunjukkan bahwa pengetahuan sangat berpengaruh terhadap tingkat kecemasan seseorang. Sesuai dengan teori yang ada bahwa pengetahuan yang rendah mengakibatkan seseorang mudah mengalami kecemasan.

Pengetahuan adalah merupakan hasil "tahu" dan ini terjadi setelah orang mengadakan penginderan terhadap suatu objek tertentu. Penginderaan terhadap obyek terjadi melalui panca indra manusia yakni penglihatan, pendengaran, penciuman, rasa dan raba dengan sendiri. Pada waktu pengindraan sampai menghasilkan pengetahuan tersebut sangat dipengaruhi oleh intensitas perhatian persepsi terhadap obyek. Sebagian besar pengetahuan manusia diperoleh melalui mata dan telinga. [13]

Dari penjelasan diatas dapat diketahui bahwa seseorang akan memperoleh pengetahuan dari hasil penginderaan tetapi setiap orang memiliki daya ingat dan daya tangkap yang berbeda-beda. Pengetahuan yang kurang dipengaruhi oleh beberapa faktor yaitu faktor internal meliputi umur, jenis kelamin, pendidikan, pekerjaan, dan faktor eksternal yang meliputi lingkungan, sosial budaya, status ekonomi, sumber informasi. Kurangnya pengetahuan bisa menimbulkan kecemasan pada wanita dalam menghadapi menopause.

Dari penelitian didapatkan sebagian besar responden mengalami kecemasan ringan.

Kecemasan merupakan keadaan perasaan afektif yang tidak menyenangkan yang disertai dengan sensasi fisik yang memperingatkan orang terhadap bahaya yang akan datang. Keadaan yang tidak menyenangkan itu sering kabur dan sulit menunjuk dengan tepat, tetapi kecemasan itu sendiri selalu dirasakan.[12]

Kecemasan dapat muncul akibat kurangnya seseorang dalam memperoleh pengetahuan, ilmu dan informasi. Oleh karena itu diperlukan peran serta kader dan tenaga kesehatan untuk memberikan informasi melalui penyuluhan agar ibu lebih memahami tanda-tanda menopause sehingga siap menerima keadaannya tanpa diliputi kecemasan yang berlebihan. Dari penyuluhan tersebut diharapkan wanita premenopause mendapatkan pengetahuan sehingga mengetahui gejala yang akan dan telah terjadi pada dirinya menjelang masa menopause. Dengan demikian, diharapkan ibu dapat menjalani masa menopause dengan nyaman tanpa adanya rasa cemas.

\section{SIMPULAN}

Berdasarkan penelitian yang telah dilakukan dengan judul "Hubungan Pengetahuan dengan Tingkat Kecemasan Wanita Premenopause dalam Menghadapi Masa Menopause RT 15-17 di Dusun Tirto Mulyo Desa Joho Kecamatan Wates Kabupaten Kediri", pada 36 responden dapat diambil kesimpulan bahwa "Ada

Jurnal Kebidanan Vol 9 No 2 Oktober 2020 | 118 


\section{JURNAL KEBIDANAN}

hubungan antara pengetahuan dengan tingkat kecemasan wanita premenopaause dalam menghadapi masa menopause

\section{REFRENSI}

[1] N. Mulyani, Menopause Akhir Siklus Menstruasi pada Wanita di Usia Pertengahan. Yogyakarta: Nuha Medika, 2013.

[2] Proverawati, Menopause dan Sindrome Premenopause. Yogyakarta: Nuha Medika, 2010.

[3] Sukarni, Kehamilan,Persalinan,dan Nifas. Yogyakarta: Nuha Medika, 2013.

[4] D. Ramadhani, Cynthia., "Gambaran Pengetahuan Ibu Tentang Persiapan Fisik Dan Psikis Memasuki Masa Menopause," J. Kesehat. Vokasional, vol. 4 No.2, 2019, [Online]. Available: https://jurnal.ugm.ac.id/jkesvo.

[5] S. Nurpatminingsih, "Hubungan Antara Tingkat Kesiapan Menopause dengan Kecemasan Menghadapi Menopause pada Ibu.," 2016, [Online]. Available: eprints.ums.ac.id/44773/1/NASKAH PUBLIKASI.pdf .
[6] Dinkes Kabupaten Kediri, "Data Profil Kesehatan Kabupaten Kediri," 2017. .

[7] Y. Suparni, E. \& Trisnawati, "Hubungan Gangguan Masa Menopause dengan Tingkat Kecemasan pada Ibu Menopause," Eduhealth, vol. 4 No. 2, 2014, [Online]. Available: journal.unipdu.ac.id/index.php/eduhealth/article/d ownload/456/403 .

[8] L. Lubis, Psikologi Kespro Wanita dan Perkembangan Reproduksinya. Jakarta: Kencana Prenada Media Group, 2013.

[9] A. A. Hidayat, Metode Penelitian Kebidanan Dan Teknik Analis Data. Jakarta: Salemba Medika, 2014.

[10] Nursalam, Metodologi Penelitian Ilmu Keparawatan. Jakarta: Salemba Medika, 2013.

[11] A. P. Ariyani, Aplikasi Metodologi Penelitian Kebidanan dan Kesehatan Reproduksi. Yogyakarta: Nuha Medika, 2014.

[12] L. Lestari, Psikologi Kespro Wanita dan Perkembangan Reproduksinya. Yogyakarta: Nuha Medika, 2015.

[13] Wawan \& Dewi, Teori Dan Pengukuran Pengetahuan, Sikap, Dan Prilaku Manusia. Yogyakarta: Nuha Medika, 2010. 